\title{
Modeling and Simulation of the Heat Transfer Behaviour of a Shell-and-Tube Condenser for a Moderately High-Temperature Heat Pump
}

\author{
Tzong-Shing Lee and Jhen-Wei Mai \\ Department of Energy and Refrigerating Air-Conditioning Engineering \\ National Taipei University of Technology, Taipei \\ Taiwan
}

\section{Introduction}

For many countries, increasing energy efficiency and reducing greenhouse gas emissions are key countermeasures to cope with the energy crisis and climate change. Of the various heating equipment such as heat pumps, gas-fired boilers, oil-fired boilers, or electric boilers, heat pumps are widely adopted for space heating, water heating, and process heating by households, business, and industry due to high energy efficiency and effective reduction of greenhouse gases. The main components in a heat pump include the compressor, the expansion valve and two heat exchangers referred to as evaporator and condenser. Condenser is the essential component for heat pump transferring heat from refrigerant-side to water-side. Among many types of heat exchangers, shell-and-tube condensers are probably the most common type for using in heat pump as a heat exchanger for heating water, because of their relatively simple manufacturing and adaptability to various operating conditions.

When heat pumps are used for residential and commercial hot water supply, the outlet water temperature of condenser is generally kept below $60^{\circ} \mathrm{C}$. However, when heat pumps are used for process heating, the hot water outlet water temperature of condenser can range anywhere from 60 to $95^{\circ} \mathrm{C}$. Such heat pumps are referred to as a moderately hightemperature heat pump. Under such operating conditions, the shell-and-tube condensers may face several issues: (1) the temperature difference between hot water inlet and outlet temperatures is high; generally above $40 \mathrm{~K}$ and even up to $60 \mathrm{~K}$; (2) the condensing temperature increases as the outlet temperature increases contributing to the increase in the sensible heat ratio of refrigerants during the condensing process by as much as $25 \%$; (3) as condensing temperature increases, the discharge temperature of compressor also increases, resulting in a decrease in energy efficiency of heat pump units. Therefore, under conditions of large temperature difference, high sensible heat ratio, and high outlet water temperature, how to effectively recover sensible heat, reduce condensing temperature, and thus improve the performance of heat pump units have become key challenges for this type of shell-and-tube condenser design. Because the factors that can influence heat transfer performance of heat exchangers are many, including flow arrangement, tube size, geometric configuration, and inlet/outlet conditions on the water 
and refrigerant sides, in order to effectively shorten or reduce the time and cost in the development and design of this type of heat exchanger, computer-aided design of moderately high-temperature heat pump condensers, as well as relevant simulation studies, is worth further investigation.

Lately, several studies dealt with shell-and-tube heat exchangers. Kara \& Güraras (2004) made a computer-based design model for preliminary design of shell-and-tube heat exchangers with single-phase fluid flow both on shell and tube side. The program determined the overall dimensions of the shell, the tube bundle, and optimum heat transfer surface area required to meet the specified heat transfer duty by calculating minimum or allowable shell side pressure drop, and selected an optimum exchanger among total number of 240 exchangers. Moita et al. (2004) summarized the current existing criteria in a general design algorithm to show a path for the calculations of the main design variables of shelland-tube heat exchangers. They also introduced an economic strategy design algorithm to allow a feasible design which minimizes the cost of heat exchanger. Karlsson \& Vamling (2005) carried out a 2-D CFD calculations to investigate the behaviour of vapor flow and the rate of condensation for a geometry similar to a real shell-and-tube conenser with 100 tubes.

It is shown that: (1) The vapour flow behaviour for a zeotropic mixed refrigerant in a shelland-tube condenser is complex and can be significantly different from that for a pure refrigerant. (2) The clearance size between the tube bundle and the shell has no greater influence on the flow field for the mixed refrigerant, but it has an influence on the flow field for pure refrigerant. (3) Small adjustments of the inlet design can influence the average heat flux by up to $24 \%$ for a low temperature driving force, and up to $8 \%$ for a high temperature driving. force. Karno \& Ajib (2006) developed a new model for calculation, simulation and optimization of shell-and-tube heat exchangers, and investigated the effects of transverse and longitudinal tube pitch in the in-line and staggered tube arrangements on Nusselt numbers, heat transfer coefficients, and thermal performance of the heat exchangers. It is shown that a good agreement is observed between the calculated values and the lierature values. Selbas et al. (2006) presented a method using genetic algorithms (GA) to find the optimal design parameters of a shell-and-tube heat exchanger and using LMTD method to determine the heat transfer area for a given design configuration. Allen \& Gosselin (2008) presented a model for estimating the total cost of shell-and-tube heat exchangers with condensation in tubes or in the shell, as well as a designing strategy for minimizing this cost. The optimization process is based on a genetic algorithm, and two case studies are presented. Patel \& Rao (2010) presented particle swarm optimization (PSO) for design optimization of shell-and-tube heat exchangers from economic view point. Three design variables such as shell internal diameter, outer tube diameter and baffle spacing are considered for optimization. Triangle and square tube layout were also considered for optimization. Four different case studies were presented to demonstrate the effectiveness and accuracy of the proposed algorithm. And the results were compared with those obtained by using genetic algorithm (GA). Wang et al. (2010) experimentally studied flow and heat transfer characteristics of the shell-and-tube heat exchanger with continuous helical baffles (CH-STHX) and segmental baffles (SG-STHX). Experimental results that the CH-STHX can increase the heat transfer rate by 7-12\% than the SG-STHX for the same mass flow rate although its effective heat transfer area had $4 \%$ decrease. The heat transfer coefficient and pressure drop of the CH-STHX also had $43-53 \%$ and $64-72 \%$ increase than 
those of the SG-STHX. Li et al. (2010) investigated the flow field and the heat transfer characteristics of a shell-and-tube heat exchanger for the cooling of syngas. The results show that higher operation pressure can improve the heat transfer, however brings bigger pressure drop. The components of the syngas significantly affect the pressure drop and the heat transfer. The arrangement of the baffles influences the fluid flow. Ghorbani et al. (2010) studied an experimental investigation of the mixed convection heat transfer in a coil-in-shell heat exchanger for various Reynolds and Rayleigh numbers, various tube-to-coil diameter ratios and dimensionless coil pitch. They purposed to assess the influence of the tube diameter, coil pitch, shell-side and tube-side mass flow rate over the performance coefficient and modified effectiveness of vertical helical coiled tube heat exchangers. It was found that the mass flow rate of tube-side to shell-side ratio was effective on the axial temperature profiles of heat exchanger. Vera-Garcia et al. (2010) proposed a simplified model of shelland-tubes heat exchangers, and it is implemented and tested in the modelization of a general refrigeration cycle by using $\mathrm{R} 22$, the results are compared with data obtained from a specific test bench for the analysis of shell-and-tubes heat exchangers.

Throughout the literature review, the study on the modeling and simulation of a shelland-tube condenser utilizing in moderately high-temperature heat pumps is still lacking. This chapter will present a study experimentally and theoretically investigating the heat transfer modeling of a new shell-and-tube condenser with longitude baffels, designed for an air-source moderately high-temperature heat pump water heater. Experimental data and theoretical methods were applied in order to develop a theoretical model that can simulate the heat transfer behavior of this type of heat exchanger. Cases study for sizing and rating of the heat exchanger was then demonstrated. Some topics will be covered in this chapter:

i. Experimental measurements of the shell-and-tube condenser,

ii. Modeling, and validation of the heat transfer behavior of the shell-and-tube condenser

iii. Cases study for sizing and rating by using modified model.

The results of this study can be used as a reference in development of computer-aided design and simulation of heat transfer performance of shell-and-tube condensers for moderately high-temperature heat pumps.

\section{Experimental setup and test conditions}

\subsection{Experimental apparatus}

An air-source moderately high-temperature heat pump system with its condenser for heating water has been built and tested in this study. The aims of this study were focused mainly on the heat transfer performance of the new condenser designed for operating under large temperature difference, high sensible heat ratio, and high outlet water temperature. Figure 1 shows the schematic diagram of the experimental setup and the location of the sensors. The testing system consists of a compressor, a condenser, a throttling device, and an evaporator. R134a was selected as the working refrigerant in the testing system. The compressor is a type of semi-hermetic scroll with a displacement volume of $46.5 \mathrm{~m}^{3} / \mathrm{hr}$. The condenser, shown in Figure 2 and 3, is a type of shell-and-tube heat exchanger with longitude baffles, twelve tube passes, and 48 copper tubes. The evaporator is a cross flow air-to-refrigerant heat exchanger of finned-tube type. The throttling device is a thermostatic 
expansion valve with an external equalizer. Heat released from the condenser is transferred to water while the evaporator takes heat from air in a controlled environment room as heat source. The temperature and humidity of ambient air entering to the finned-tube evaporator was controlled by a testing facility used to conduct the heat pump experiment. The inlet water temperature is adjusted by circulating the generated hot water and mixing with colder water from both cooling tower and water main supply. The temperatures of water, refrigerant, and air at various points in the heat pump system were measured by $\mathrm{T}$ type thermocouples with an accuracy of $\pm 0.1 \mathrm{~K}$. The measurement of refrigerant pressures is made by calibrated pressure transducers with an accuracy of $\pm 0.15 \%$. The water flow rate of condenser is measured by an electromagnetic flowmeter with accuracy of $\pm 0.5 \%$, while the power consumed by compressor and fan are measured by power meter with an accuracy of $\pm 0.5 \%$.

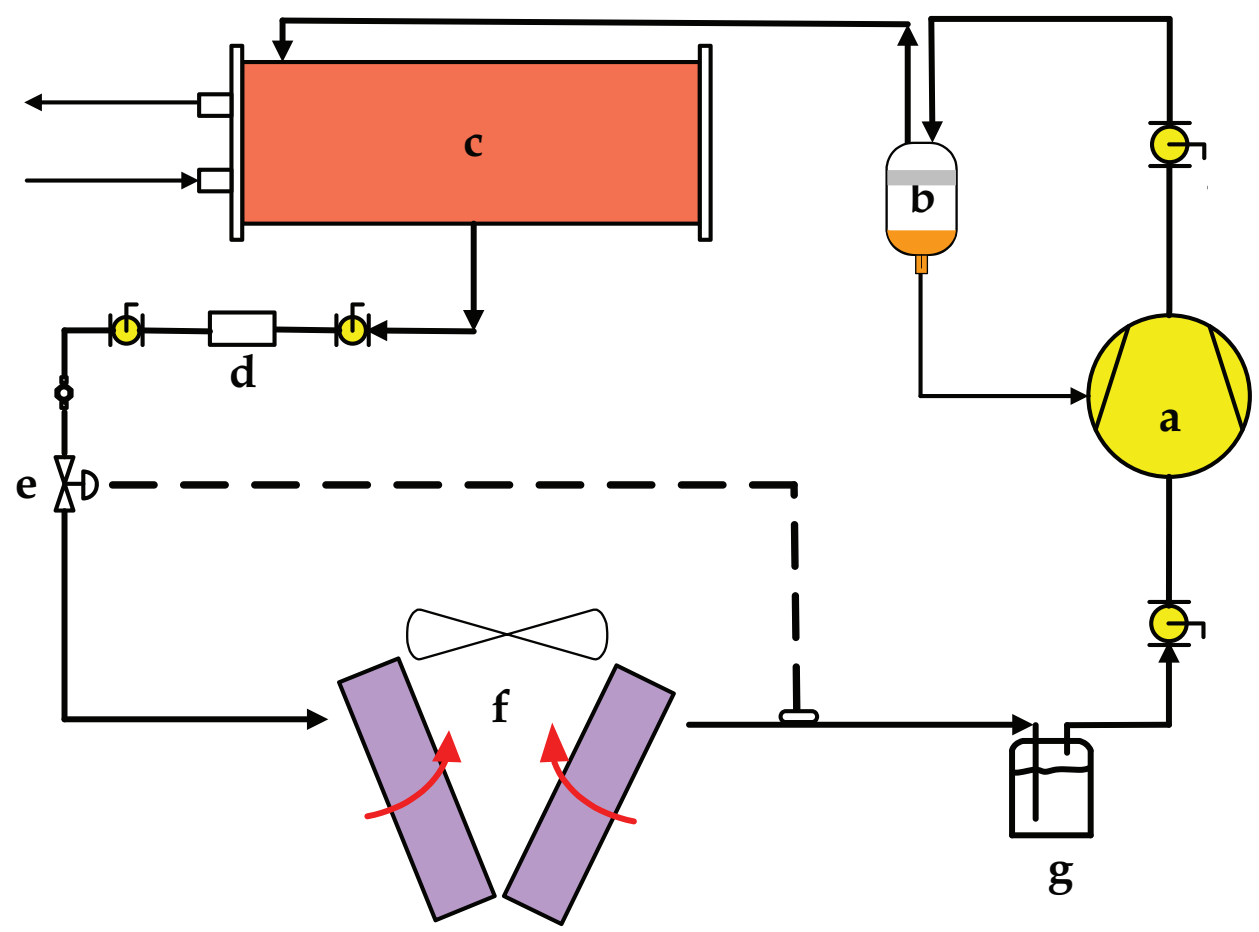
a. compressor
b. oil separator
c. condenser
d. dryer
e. expansion valve
f. evaporator
g. liquid-gas separator

Fig. 1. Schematic diagram of an air-source moderately high-temperature heat pump system 


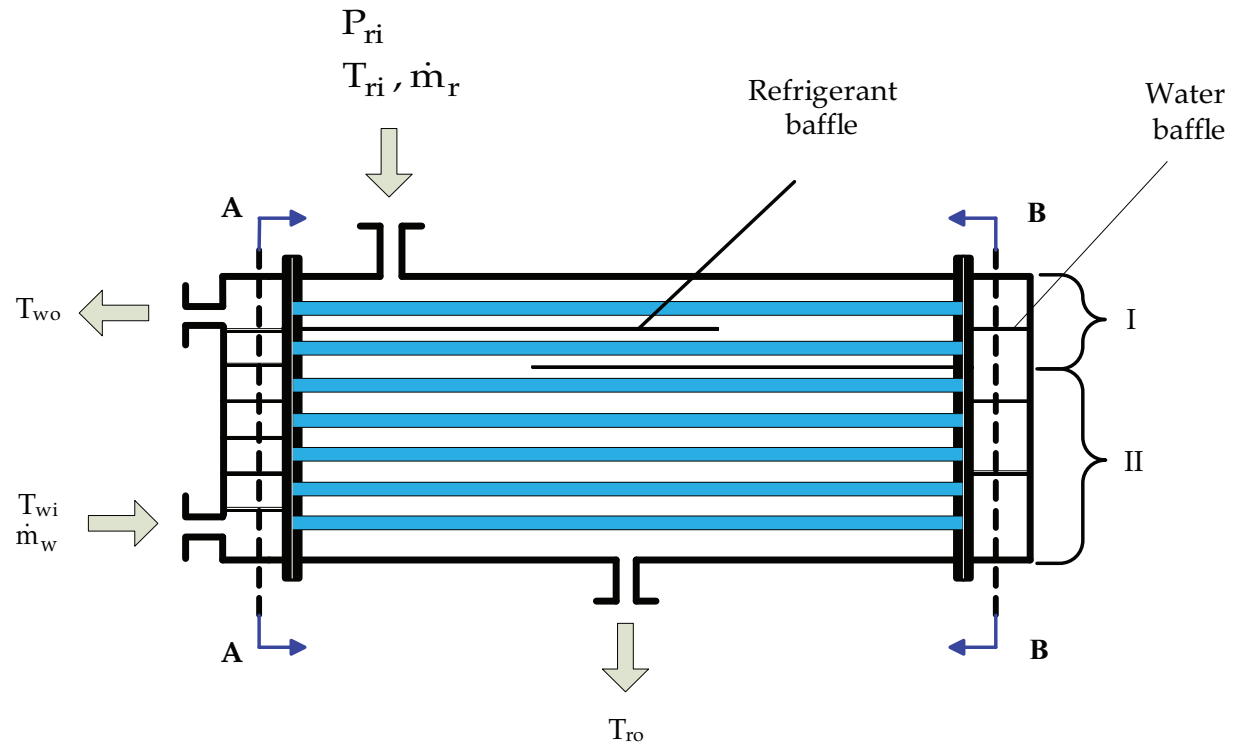

Fig. 2. Schematic diagram of the shell-and-tube condenser with longitude baffles

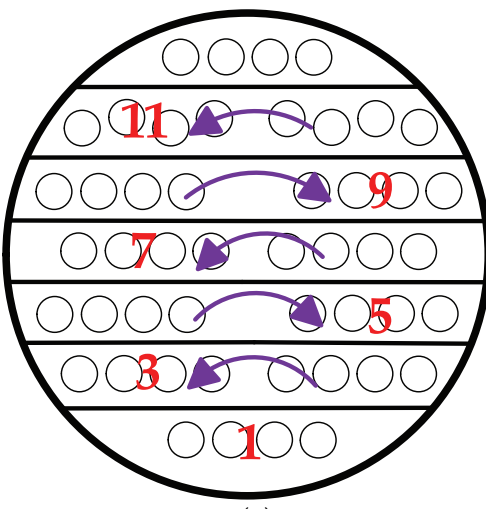

(a)

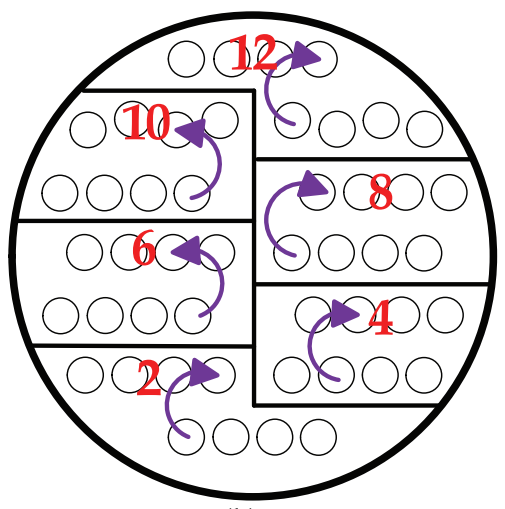

(b)

Fig. 3. Passes layout for the shell-and-tube condenser (a) A-A section view, (b) B-B section view

\subsection{Test condition and procedures}

The experimental parameters of this work are inlet and outlet states of refrigerant, inlet and outlet water temperatures, and water flow rate passing through condenser. In order to investigate the effect of those parameters on the heating capacity and performance of moderately high-temperature air-source heat pump, this work conducted 27 experiments. The detail of testing conditions of this work is listed in Table 1. The test data sets were acquired and recorded every five minutes intervals through the data logger system 
connected to a notebook computer after the testing system operation had reached steady state. The reliability of experimental data recorded was confirmed by energy balance method with less than $5 \%$ between the measured and calculated values.

\subsection{Data reduction}

The heating capacity of shell-and-tube condenser for heat pump can be determined as follows.

$$
\dot{Q}_{H}=\dot{F}_{c} \rho_{w} c_{p w}\left(T_{w o}-T_{w i}\right)[\mathrm{kW}]
$$

where $\dot{F}_{c}$ is the volumetri flow rate of water, $\rho_{w}$ is the density of water $c_{p w}$ is the specific heat of water, $T_{w i}$ and $T_{w o}$ represent the inlet and outlet water temperatures, respectively.

\section{Mathematical models}

\subsection{Heat transfer rate}

In the shell-and-tube condenser as shown in Fig. 2, water flows inside the tubes and refrigerant flows outside the tubes through the shell. The heat transfer rate between refrigerant and water can be determined in three ways:

$$
\dot{Q}_{\text {Model }}=\dot{Q}_{r}=\dot{Q}_{w}
$$

and

$$
\begin{gathered}
\dot{Q}_{\text {Model }}=U A F \Delta T_{m} \\
\dot{Q}_{r}=\dot{m}_{r}\left(h_{r i}-h_{r o}\right) \\
\dot{Q}_{w}=\dot{m}_{w} c_{p w}\left(T_{w o}-T_{w i}\right)
\end{gathered}
$$

where $\dot{Q}_{\text {Model }}$ is the heat transfer rate determined by Eq.(3) [kW], $\dot{Q}_{r}$ is the heat transfer rate determined by refrigerant-side data $[\mathrm{kW}], \dot{Q}_{w}$ is the heat transfer rate determined by water-side data $[\mathrm{kW}], U$ is the overall heat transfer coefficient $\left[\mathrm{W} / \mathrm{m}^{2 \circ} \mathrm{C}\right], A$ is the heat transfer area $\left[\mathrm{m}^{2}\right], F$ is a correction factor, $\Delta T_{m}$ represents $\log$ mean temperature difference, $\dot{m}_{r}$ is the mass flow rate of refrigerant $[\mathrm{kg} / \mathrm{s}], h_{r i}$ and $h_{r o}$ are, respectively, the inlet and outlet enthalpy of refrigerant $[\mathrm{kJ} / \mathrm{kg}], \dot{m}_{w}$ is the mass flow rate of water $[\mathrm{kg} / \mathrm{s}]$, $c_{p w}$ is the specific heat of water $[\mathrm{kJ} / \mathrm{kgK}], T_{w i}$ and $T_{w o}$ are the inlet and outlet temperature of water $\left[{ }^{\circ} \mathrm{C}\right]$, respectively.

\subsection{Heat transfer area}

The heat transfer area (A) of the shell-and-tube condenser is computed by:

$$
A=L \pi d_{0} N_{t}
$$

where $L$ is the tube length $[\mathrm{m}], d_{0}$ is the tube outside diameter $[\mathrm{m}]$, and $N_{t}$ is the number of tubes. 


\subsection{Correction factor}

In design the heat exchangers, a correction factor is applied to the log mean temperature difference (LMTD) to allow for the departure from true countercurrent flow to determine the true temperature difference. The correction factor $F$ for a multi-pass and crossflow heat exchanger and given for a two-pass shell-and-tube heat exchangers is calculated by (Kara \& Güraras, 2004):

$$
F=\frac{\sqrt{R^{2}+1} \ln \left(\frac{1-P}{1-P R}\right)}{(R-1) \ln \left\{\left[\frac{2-P\left(R+1-\sqrt{R^{2}+1}\right.}{2-P\left(R+1+\sqrt{R^{2}+1}\right)}\right]\right\}}
$$

and

$$
\begin{gathered}
P=\frac{\left(T_{c o}-T_{c i}\right)}{\left(T_{h i}-T_{c i}\right)} \\
R=\frac{\left(T_{h i}-T_{h o}\right)}{\left(T_{c o}-T_{c i}\right)}
\end{gathered}
$$

where $\mathrm{P}$ is the thermal effectiveness, and $\mathrm{R}$ is the heat capacity flow-rate ratio. The value of correction factor for a condenser is 1 , regardless of the configuration of the heat exchanger (Hewitt, 1998).

\subsection{Log-mean temperature difference}

The log mean temperature difference $\Delta \mathrm{T}_{\mathrm{m}}$ for countercurrent flow is determined by:

$$
\Delta T_{m}=\frac{\left(T_{h i}-T_{c o}\right)-\left(T_{h o}-T_{c i}\right)}{\ln \frac{T_{h i}-T_{c o}}{T_{h o}-T_{c i}}}
$$

where $T_{h i}$ and $T_{h o}$ are, respectively, the inlet and outlet temperature for hot fluid, $T_{c i}$ and $T_{c o}$ are the inlet and outlet temperature for cool fluid, respectively.

\subsection{Overall heat transfer coefficient}

Overall heat transfer coefficient $U$ depends on the tube inside diameter, tube outside diameter, tube side convective coefficient, shell side convective coefficient, tube side fouling resistance, shell side fouling resistance, and tube material, which is given by (Kara \& Güraras, 2004):

$$
U=\frac{1}{\frac{1}{h_{s}}+\frac{d_{o} \ln \left(\frac{d_{o}}{d_{i}}\right)}{2 k_{m}}+R_{f o}+\frac{d_{o}}{d_{i}}\left(R_{f i}+\frac{1}{h_{t}}\right)}
$$

where $h_{s}$ is the shell-side heat transfer coefficient $\left[\mathrm{W} / \mathrm{m}^{2} \mathrm{~K}\right], h_{t}$ is the tube-side heat transfer coefficient $\left[\mathrm{W} / \mathrm{m}^{2} \mathrm{~K}\right], d_{i}$ and $d_{o}$ are, respectively, the inside and outside diameters of tubes 
[m], $k_{m}$ is the thermal conductivity $[\mathrm{W} / \mathrm{mK}], R_{f i}$ and $R_{f o}$ are the tube-side and shell-side fouling resistances $\left[\mathrm{m}^{2} \mathrm{~K} / \mathrm{W}\right]$, respectively.

\subsection{Shell-side heat transfer coefficient in single phase flow}

In this work, the shell-side heat transfer coefficient $h_{s}$ in single phase flow is given by (Kern, 1950):

$$
N u_{s}=\frac{h_{s} D_{e}}{k_{s}}=0.36 \operatorname{Re}_{s}^{0.55} \operatorname{Pr}_{s}^{1 / 3}\left(\frac{\mu_{s}}{\mu_{\text {wts }}}\right)^{0.14}
$$

and

$$
\begin{gathered}
\operatorname{Re}_{s}=\frac{\dot{m}_{s} D_{e}}{A_{s} \mu_{s}} \\
D_{e}=\frac{4\left[0.86 P_{T}^{2}-\left(\frac{\pi d_{o}^{2}}{4}\right)\right]}{\pi d_{o}} \quad \text { for triangular pitch } \\
A_{s}=D_{i} B\left(1-\frac{d_{o}}{P_{T}}\right) \\
\operatorname{Pr}_{s}=\frac{\mu_{s} c_{p s}}{k_{s}}
\end{gathered}
$$

where $D_{e}$ is the hydraulic diameter $[\mathrm{m}], \dot{m}_{s}$ is the mass flow rate of refrigerant $[\mathrm{kg} / \mathrm{s}], \mu_{s}$ is dynamic viscosity [Pa-s], $\mu_{w t s}$ is wall dynamic viscosity [Pa-s], $d_{0}$ is the tube outside diameter[m], $P_{T}$ is the tube pitch $[\mathrm{m}]$, As is the shell-side pass area $\left[\mathrm{m}^{2}\right], \mathrm{Di}$ is inside diameter $[\mathrm{m}], \mathrm{B}$ is the baffles spacing $[\mathrm{m}], \mathrm{cps}$ is the specific heat $[\mathrm{kJ} / \mathrm{kgK}]$, and $k_{s}$ is the thermal conductivity $[\mathrm{W} / \mathrm{mK}]$.

\subsection{Shell-side heat transfer coefficient in condensation flow}

The average heat transfer coefficient $h_{s}$ for horizontal condensation outside a single tube is given by the equation (Edwards, 2008):

$$
h_{s}=C\left[\frac{k_{f}^{3} \rho_{f}^{2} g h_{f g}}{\mu_{f} d_{o} \Delta T_{f}}\right]^{0.25}
$$

where $C=0.943, k_{f}$ is the film thermal conductivity $[\mathrm{W} / \mathrm{mK}], \rho_{f}$ is the film density $\left[\mathrm{kg} / \mathrm{m}^{3}\right], \mu_{f}$ is the film dynamic viscosity[Pa s], $h_{f g}$ is the latent heat of vaporization $[\mathrm{J} / \mathrm{kg}], g$ is gravitational acceleration $\left[\mathrm{m} / \mathrm{s}^{2}\right], d_{o}$ is the tube outside diameter $[\mathrm{m}], \Delta T_{f}$ is the film temperature difference $\left[{ }^{\circ} \mathrm{C}\right]$.

For a bundle of $N_{t}$ tubes, the heat transfer coefficient can be modified by the Eissenberg expression as following (Kakac \& Liu, 2002):

$$
\frac{h_{N}}{h_{1}}=0.60+0.42 N^{-1 / 4}
$$


where $\mathrm{hN}$ is the average heat transfer coefficient for a vertical column of $N$ tubes, and $h_{1}$ is the heat transfer coefficient of the top tube in the row.

\subsection{Tube-side heat transfer coefficient}

According to flow regime, the tube-side heat transfer coefficient $h_{t}$ can be computed by following relations (Patel \& Rao, 2010):

$$
\begin{gathered}
N u_{t}=\frac{h_{t} d_{i}}{k_{t}}=\left[3.657+\frac{0.0677\left(\operatorname{Re}_{t} \operatorname{Pr}_{t} \frac{d_{i}}{L}\right)^{1.33}}{1+0.1 \operatorname{Pr}_{t}\left(\operatorname{Re}_{t} \frac{d_{i}}{L}\right)^{0.3}}\right] \quad \text { for } \operatorname{Re}_{t}<2300 \\
N u_{t}=\frac{h_{t} d_{i}}{k_{t}}=\left\{\frac{\frac{f_{t}}{8}\left(\operatorname{Re}_{t}-1000\right) \operatorname{Pr}_{t}}{1+12.7 \sqrt{\frac{f_{t}}{8}}\left(\operatorname{Pr}_{t}^{0.67}-1\right)}\left[1+\left(\frac{d_{i}}{L}\right)^{0.67}\right]\right\} \text { for } 2300<\operatorname{Re}_{t}<10000 \\
N u_{t}=\frac{h_{t} d_{o}}{k_{t}}=0.027 \operatorname{Re}_{t}^{0.8} \operatorname{Pr}_{t}^{1 / 3}\left(\frac{\mu_{t}}{\mu_{w t}}\right)^{0.14} \quad \text { for } \operatorname{Re}_{t}>10000
\end{gathered}
$$

and

$$
\begin{gathered}
\operatorname{Re}_{t}=\frac{\rho_{t} v_{t} d_{i}}{\mu_{t}} \\
v_{t}=\frac{\dot{m}_{t}}{\frac{\pi d_{o}^{2}}{4} \rho_{t}} \frac{n_{p}}{N_{t}} \\
\operatorname{Pr}_{t}=\frac{\mu_{t} c_{p t}}{k_{t}} \\
\mathrm{f}_{\mathrm{t}}=\left(1.82 \log _{10} \operatorname{Re}_{t}-1.64\right)^{-2}
\end{gathered}
$$

where $N u_{t}$ is tube-side Nusselt number, $R e_{t}$ is tube-side Reynolds number, $P r_{t}$ is tube-side Prandtl number, $k_{t}$ is the thermal conductivity $[\mathrm{W} / \mathrm{mK}], d_{i}$ is the tube inside diameter $[\mathrm{m}], L$ is tube length $[\mathrm{m}], v_{t}$ is tube-side fluid velocity $[\mathrm{m} / \mathrm{s}], \dot{m}_{t}$ is tube-side mass flow rate $[\mathrm{kg} / \mathrm{s}], d_{o}$ is tube outside length $[\mathrm{m}], \rho_{t}$ is tube-side density $\left[\mathrm{kg} / \mathrm{m}^{3}\right], n_{p}$ is number of tube passes, $N_{t}$ is number of tubes, $\mu_{t}$ is viscosity at tube wall temperature [Pa-s], $\mu_{w t}$ is viscosity at core flow temperature [Pa-s], $f_{t}$ is Darcy friction factor (Hewitt, 1998).

\subsection{Coefficient of variation of root-mean-square error}

This study uses the coefficient of variation of root-mean-square error (CV) to indicate how well the model predicting value fits the experimental data, defined as follows: 


$$
C V=\frac{\sqrt{\frac{\sum_{i=1}^{n}\left(y_{i}-x_{i}\right)^{2}}{n}}}{\left|\frac{\sum_{i=1}^{n} y_{i} \mid}{n}\right|} \times 100 \%
$$

where $x_{i}$ is the predicting value by present model, $y_{i}$ is experimental data, and $n$ is the number of experimental data set.

\subsection{Solution procedures}

According to the configuration of the horizontal baffles in the heat exchanger, the condenser can be separate into two regions, Section-I and II, as indicated in Figure 2-4. Section-I has three tube passes and two horizontal baffles, while Section-II has nine tube passes without any horizontal baffle. In Section-I, both water and refrigerant are in single phase. The temperature variations of the refrigerant and water streams are shown in Figure 4 . In the interface between Section-I and II, the entering water temperature $T_{w}$ and the leaving refrigerant temperature $\operatorname{Tr}$ should be determined by iteration method.

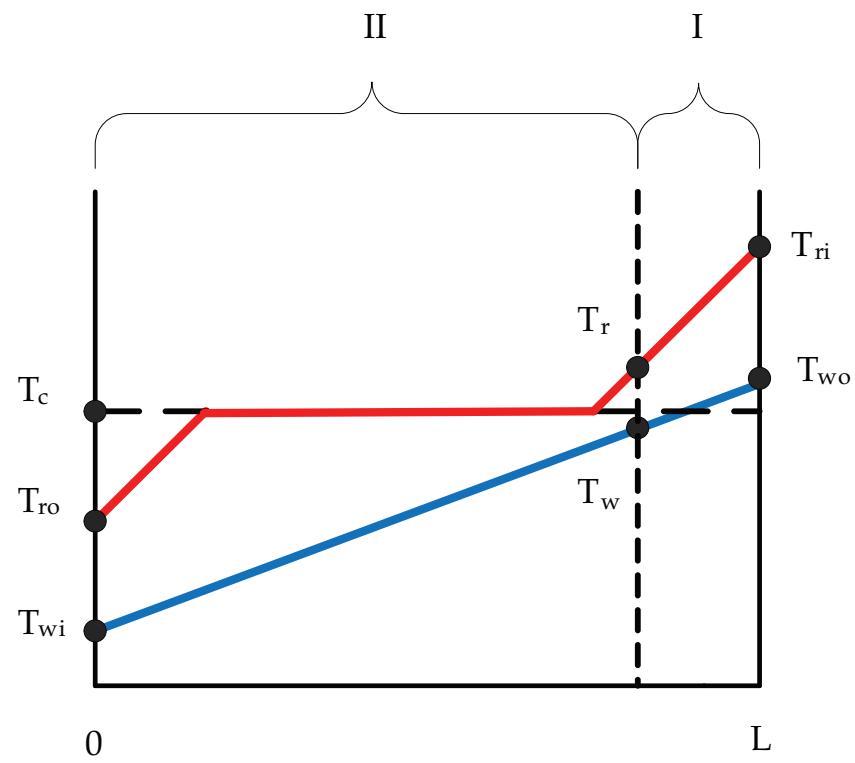

Fig. 4. Temperature variations of two steams in the condenser

The total heat transfer rate of the condenser is the sum of individual heat transfer rate of the two sections.

$$
\dot{Q}_{\text {Model }}=\dot{Q}_{\text {Model, },}+\dot{Q}_{\text {Model,II }}
$$


where $\dot{\mathrm{Q}}_{\text {Model,I }}$ and $\dot{\mathrm{Q}}_{\text {Model,II }}$ represent the heat transfer rate in Section-I and II, respectively, and can be determined as following equations.

$$
\begin{gathered}
\dot{Q}_{\text {Model }, I}=\left(U_{\text {Model }} A F \Delta T_{m}\right)_{I} \\
\dot{Q}_{\text {Model }, I I}=\left(U_{\text {Model }} A F \Delta T_{m}\right)_{I I}
\end{gathered}
$$

The overall heat transfer coefficient for the two sections can be calculated by

$$
\begin{aligned}
& U_{\text {Model, } \mathrm{I}}=\frac{1}{\frac{1}{h_{s, I}}+\frac{d_{o} \ln \left(\frac{d_{o}}{d_{i}}\right)}{2 k_{m}}+R_{f o}+\frac{d_{o}}{d_{i}}\left(R_{f i}+\frac{1}{h_{t}}\right)} \\
& U_{\text {Model }, \mathrm{II}}=\frac{1}{\frac{1}{h_{s, I I}}+\frac{d_{o} \ln \left(\frac{d_{o}}{d_{i}}\right)}{2 k_{m}}+R_{f o}+\frac{d_{o}}{d_{i}}\left(R_{f i}+\frac{1}{h_{t}}\right)}
\end{aligned}
$$

The heat transfer areas for the two sections can be calculated as

$$
\begin{aligned}
& A_{I}=L \pi d_{0} N_{t, I} \\
& A_{I I}=L \pi d_{0} N_{t, I I}
\end{aligned}
$$

The tube-side heat transfer rates for Section-I and II are:

$$
\begin{gathered}
\dot{Q}_{w}=\dot{Q}_{w, I}+\dot{Q}_{w, I I} \\
\dot{Q}_{w, I}=\dot{Q}_{r, I}=\dot{m}_{r}\left(h_{r i}-h_{r}\right)=\left(U_{E x p} A \Delta T_{m}\right)_{I} \\
T_{w}=T_{w o}-\frac{\dot{Q}_{w, I}}{\dot{m}_{w} c_{p w}} \\
\dot{Q}_{w, I I}=\dot{m}_{w} c_{p w}\left(T_{w}-T_{w i}\right)=\left(U_{E x p} A \Delta T_{m}\right)_{I I}
\end{gathered}
$$

where the log mean temperature difference for Section-I and II can be determined by:

$$
\begin{gathered}
\Delta T_{m, I}=\frac{\left(T_{r i}-T_{w o}\right)-\left(T_{r}-T_{w}\right)}{\ln \left(\frac{T_{r i}-T_{w o}}{T_{r}-T_{w}}\right)} \\
\Delta T_{m, I I}=\frac{\left(T_{r}-T_{w}\right)-\left(T_{r o}-T_{w i}\right)}{\ln \left(\frac{T_{r}-T_{w}}{T_{r o}-T_{w i}}\right)}
\end{gathered}
$$


The present modeling procedures for determining the total heat transfer rate are shown as Fig. 5 and detailed as following steps:

1. Input design parameters and geometry factors:

Design parameters include the refrigerant inlet and outlet temperatures $\left(T_{r i}, T_{r o}\right)$, the refrigerant inlet pressure $P_{r i}$, the water inlet and outlet temperatures $\left(T_{w i}, T_{w o}\right)$, the water and refrigerant mass flow rate $\left(\dot{\mathrm{m}}_{\mathrm{w}}, \dot{\mathrm{m}}_{\mathrm{r}}\right)$, the condensing temperature $\mathrm{T}_{\mathrm{c}}$, and the number of tubes $N_{t}$. Geometry factors include the tube inside and outside diameters $\left(d_{i}, d_{0}\right)$, the shell inside diameter $D_{i}$, the baffles distance $B$, the tube pitch $P_{T}$, and the tube length $L$.

2. Initial guess a shell-side outlet temperature $\left(T_{r}\right)$ for Section-I.

3. Determine relative physical quantities for Section-I:

The physical quantities include the heat transfer areas, the shell-side hydraulic diameter, the tube-side fluid velocity, the Reynolds numbers, the tube- and shell-side heat transfer coefficients, overall heat transfer coefficient, log mean temperature difference, the heat transfer rate $\left(\dot{Q}_{w, I}\right)$ computed from water-side data and the heat transfer rate $\left(\dot{Q}_{\text {Model, }}\right)$ predicting by present model.

4. If the percent error $\left|\frac{\mathrm{Q}_{\mathrm{w}, \mathrm{I}}-\mathrm{Q}_{\mathrm{Model}, \mathrm{I}}}{\mathrm{Q}_{\mathrm{w}, \mathrm{I}}}\right|<0.01 \%$, then output $T_{r}, T_{w}, \dot{\mathrm{Q}}_{\mathrm{Model}, \mathrm{I}}$ and $\dot{\mathrm{Q}}_{\mathrm{w}, \mathrm{I}}$ and go to step 5. If not, gives a new shell-side outlet temperature and goes back to step 2. Iteration of the previous steps until the relative error is within the value of $0.01 \%$.

5. Determine relative physical quantities for Section-II:

The relative physical quantities needing to determine in the section include the heat transfer area $\left(A_{I I}\right)$, the shell-side heat transfer coefficient $\left(h_{s, I}\right)$, the overall heat transfer coefficient $\left(U_{\text {Model,III }}\right)$, the log mean temperature difference $\left(\Delta T_{m, I I}\right)$, the heat transfer rate $\left(\dot{\mathrm{Q}}_{\mathrm{w}, \mathrm{II}}\right)$ computing from water-side data, and the heat transfer rate $\left(\dot{\mathrm{Q}}_{\text {Model,II }}\right)$ predicting by present model.

6. Compute total heat transfer rate by water-side data $\left(\dot{\mathrm{Q}}_{\mathrm{w}}\right)$ and present model $\left(\dot{\mathrm{Q}}_{\text {Model }}\right)$

7. Output calculation results.

\section{Results and discussions}

A shell-and-tube condenser designed for moderately high-temperature heat pump system were built and tested in this study. Twenty-seven sets of experiment results are shown in Table 1.

By observing the data listed in Table 1, we found that, except for the data set 2-5, the water outlet temperature is higher than the condensing temperature for most data sets. These results were in line with our expectations. This is because that at the beginning of design stage, in order to effectively recover the sensible heat from superheating vapour at refrigerant-side inlet of the condenser, two horizontal baffles were placed on the refrigerantside to extend the contact time between the refrigerant and the water.

The new shell-and-tube condenser has divided into two sections, according to whether or not the refrigerant-side has placed horizontal baffles, as shown in Figure 2. By using the theoretical model and solution procedure introduced previously, numerical simulation of heat transfer behaviour was carried out for Section-I first and then for Section-II. After substituting the same conditions similar to the 27 sets of experiments, the preliminary comparison of the simulated and the experimental results are shown in Figure 6a and Figure 6b. 
Examining Figure 6a showed that the simulation results for the Section-I of condenser are very close to the deduced results from the experiment. This is because in the Section-I iteration process solving the heat transfer rates for refrigerant- and the water-side, the convergence constrain was set within $0.01 \%$ in order to meet energy conservation requirements.

The output results from Section-I calculation were set as the input data for the following Section-II calculation. The computation results for the Section-II calculation were compared to the deduced results from Eq. (34), and the difference between the two results is shown in Figure $6 \mathrm{~b}$, the CV value of Section-II is $23.01 \%$.

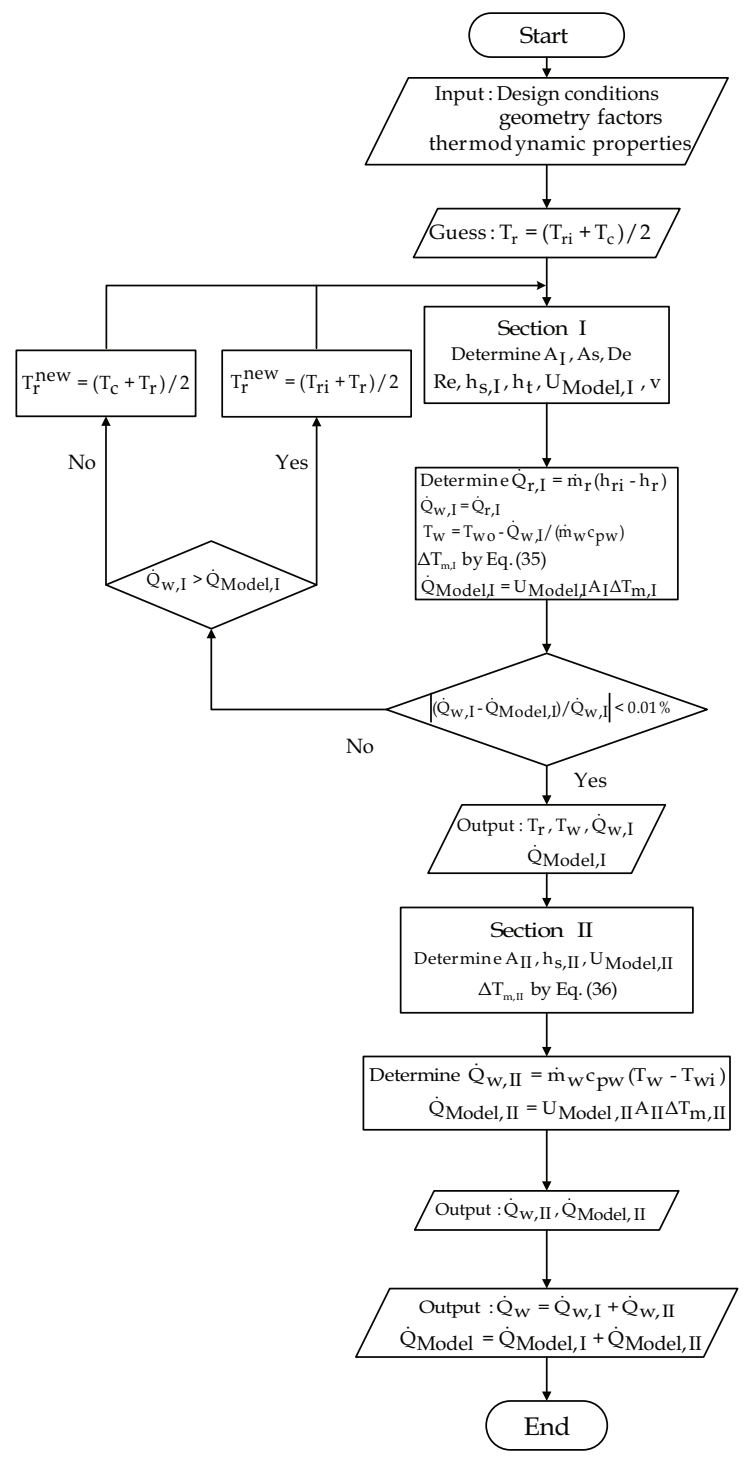

Fig. 5. Algorithm of the model 


\begin{tabular}{|c|c|c|c|c|c|c|c|c|c|}
\hline Case & $\begin{array}{c}T_{w i} \\
\left({ }^{\circ} \mathrm{C}\right)\end{array}$ & $\begin{array}{l}T_{w o} \\
\left({ }^{\circ} \mathrm{C}\right)\end{array}$ & $\begin{array}{c}\dot{m}_{w} \\
(\mathrm{~kg} / \mathrm{s})\end{array}$ & $\begin{array}{c}T_{r i} \\
\left({ }^{\circ} \mathrm{C}\right)\end{array}$ & $\begin{array}{c}P_{r i} \\
(\mathrm{MPa})\end{array}$ & $\begin{array}{c}T_{r o} \\
\left({ }^{\circ} \mathrm{C}\right)\end{array}$ & $\begin{array}{c}T_{c} \\
\left({ }^{\circ} \mathrm{C}\right)\end{array}$ & $\begin{array}{c}\dot{m}_{r} \\
(\mathrm{~kg} / \mathrm{s})\end{array}$ & $\begin{array}{c}\dot{Q}_{H} \\
(\mathrm{~kW})\end{array}$ \\
\hline 1 & 24.9 & 74.9 & 0.16 & 100.4 & 2.20 & 64.3 & 71.8 & 0.19 & 33.4 \\
\hline 2 & 25.0 & 45.1 & 0.41 & 70.5 & 1.20 & 39.1 & 46.2 & 0.18 & 35.0 \\
\hline 3 & 25.1 & 45.4 & 0.48 & 71.9 & 1.22 & 39.7 & 47.0 & 0.21 & 40.8 \\
\hline 4 & 24.9 & 55.1 & 0.27 & 80.2 & 1.50 & 46.6 & 55.2 & 0.18 & 34.6 \\
\hline 5 & 25.1 & 55.1 & 0.33 & 79.4 & 1.53 & 47.6 & 55.9 & 0.22 & 41.3 \\
\hline 6 & 25.0 & 64.9 & 0.20 & 91.0 & 1.84 & 53.6 & 63.7 & 0.18 & 34.1 \\
\hline 7 & 25.1 & 65.1 & 0.24 & 89.0 & 1.88 & 57.0 & 64.7 & 0.23 & 40.4 \\
\hline 8 & 24.9 & 70.7 & 0.16 & 97.1 & 2.09 & 59.1 & 69.4 & 0.17 & 30.5 \\
\hline 9 & 25.0 & 73.7 & 0.16 & 97.3 & 2.23 & 64.4 & 72.2 & 0.19 & 32.4 \\
\hline 10 & 25.0 & 74.0 & 0.16 & 98.0 & 2.22 & 63.7 & 72.1 & 0.19 & 32.7 \\
\hline 11 & 25.1 & 75.0 & 0.18 & 99.3 & 2.26 & 67.1 & 72.9 & 0.23 & 38.8 \\
\hline 12 & 25.1 & 75.1 & 0.18 & 99.2 & 2.24 & 71.1 & 72.5 & 0.24 & 38.1 \\
\hline 13 & 24.9 & 75.2 & 0.16 & 100.5 & 2.22 & 64.5 & 72.1 & 0.19 & 33.6 \\
\hline 14 & 24.9 & 75.4 & 0.16 & 102.9 & 2.23 & 61.0 & 72.2 & 0.19 & 33.9 \\
\hline 15 & 25.1 & 75.4 & 0.18 & 99.3 & 2.25 & 71.0 & 72.8 & 0.24 & 38.3 \\
\hline 16 & 25.2 & 78.3 & 0.16 & 104.0 & 2.34 & 68.4 & 74.5 & 0.21 & 35.5 \\
\hline 17 & 25.1 & 78.8 & 0.18 & 103.7 & 2.43 & 73.1 & 76.2 & 0.25 & 40.4 \\
\hline 18 & 25.0 & 80.0 & 0.19 & 104.1 & 2.47 & 73.8 & 76.9 & 0.28 & 44.7 \\
\hline 19 & 25.1 & 80.6 & 0.18 & 103.4 & 2.49 & 74.8 & 77.3 & 0.27 & 41.4 \\
\hline 20 & 25.1 & 84.8 & 0.14 & 106.9 & 2.65 & 78.0 & 80.2 & 0.24 & 35.6 \\
\hline 21 & 24.9 & 85.0 & 0.12 & 108.2 & 2.63 & 73.9 & 79.8 & 0.20 & 31.8 \\
\hline 22 & 34.9 & 84.3 & 0.16 & 107.4 & 2.62 & 77.8 & 79.8 & 0.22 & 32.9 \\
\hline 23 & 35.0 & 85.5 & 0.18 & 108.5 & 2.71 & 78.7 & 81.4 & 0.25 & 38.3 \\
\hline 24 & 35.1 & 85.1 & 0.19 & 109.5 & 2.70 & 78.5 & 81.0 & 0.27 & 40.7 \\
\hline 25 & 35.1 & 85.1 & 0.17 & 109.0 & 2.69 & 79.0 & 81.0 & 0.25 & 37.0 \\
\hline 26 & 39.9 & 75.2 & 0.22 & 104.3 & 2.26 & 63.5 & 72.9 & 0.19 & 33.1 \\
\hline 27 & 40.1 & 75.3 & 0.25 & 100.9 & 2.31 & 69.3 & 73.9 & 0.23 & 38.0 \\
\hline
\end{tabular}

Table 1. Experimental results 

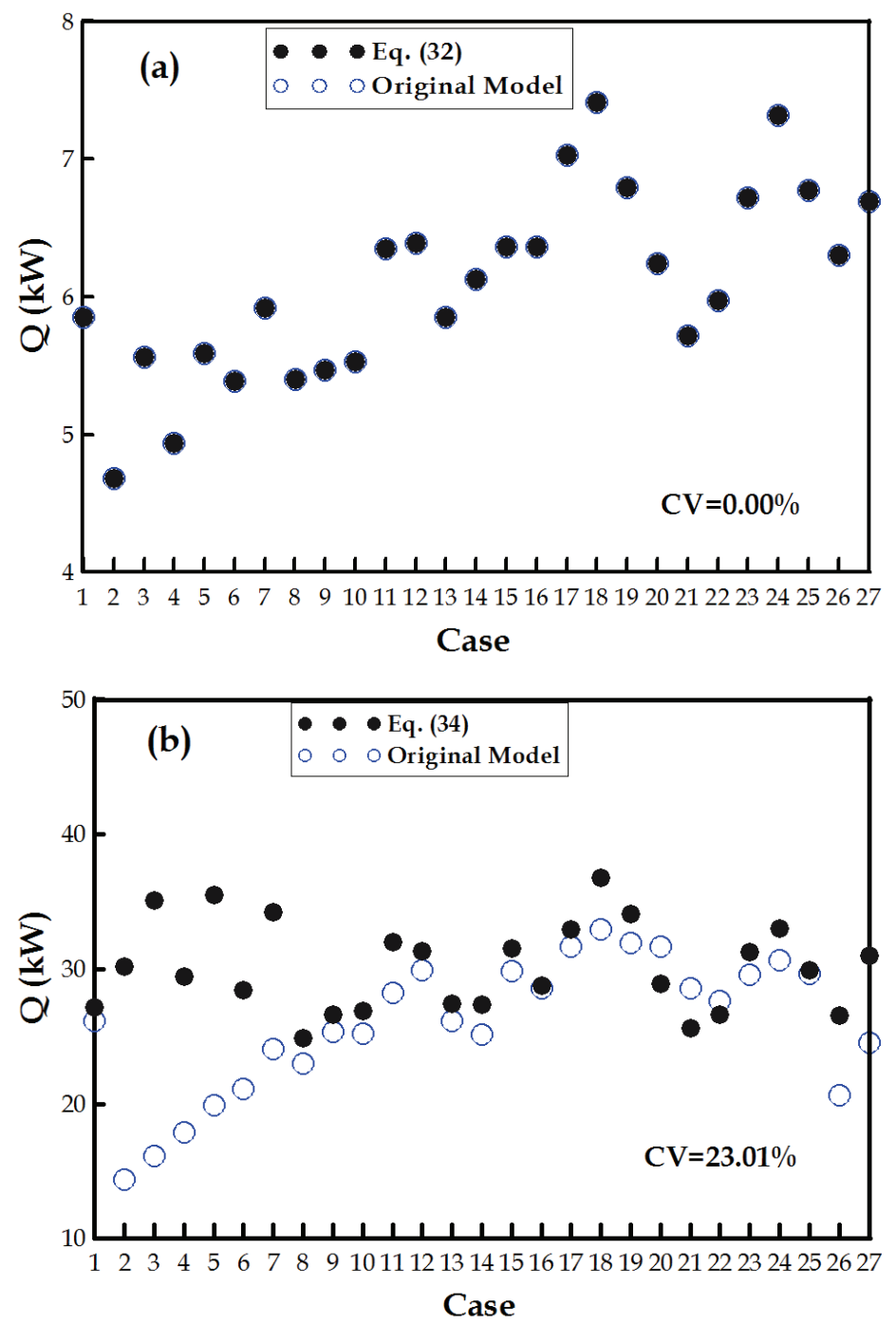

Fig. 6. The computation results of heat transfer rate for (a) Section-I and (b) Section-II

From Figure $7 \mathrm{a}$ and Figure $7 \mathrm{~b}$, the difference from data sets numbered 2-7 and 26-27 are greater than $10 \%$, the percent error for the rest data sets are all within $10 \%$. Table 1 also showed that, as compared with the other data sets, these eight cases with larger difference occurred when changing water outlet temperature and mass flow rate. We know from the theoretical model that the major variables of heat transfer rate of condenser include water inlet/outlet temperatures, water mass flow rate, and overall heat transfer coefficient $U$. Among them, the overall heat transfer coefficient is influenced by the tube-side as well as the shell-side heat transfer coefficients. The change in tube-side heat transfer coefficient is mainly due to the effect of water flow rate, while the shell-side heat transfer coefficient is 
influenced by the flow characteristic of refrigerant and tube arrangement in the condenser, which make the actual heat transfer behaviour much complex and difficult to accurately predict. Thus, observation of the effect of operating parameters on the overall heat transfer coefficient, establishment of a rule governing the overall heat transfer coefficient of the changing parameters, and the establishment of a modified correlation of heat transfer coefficient can all help increase the prediction accuracy of the model for heat transfer rate. Since in this study the hot water inlet temperature was almost constant, thus the operating parameters to be discussed include water outlet temperature $\left(T_{w o}\right)$, and water mass flow-rate $\left(\dot{m}_{w}\right)$.
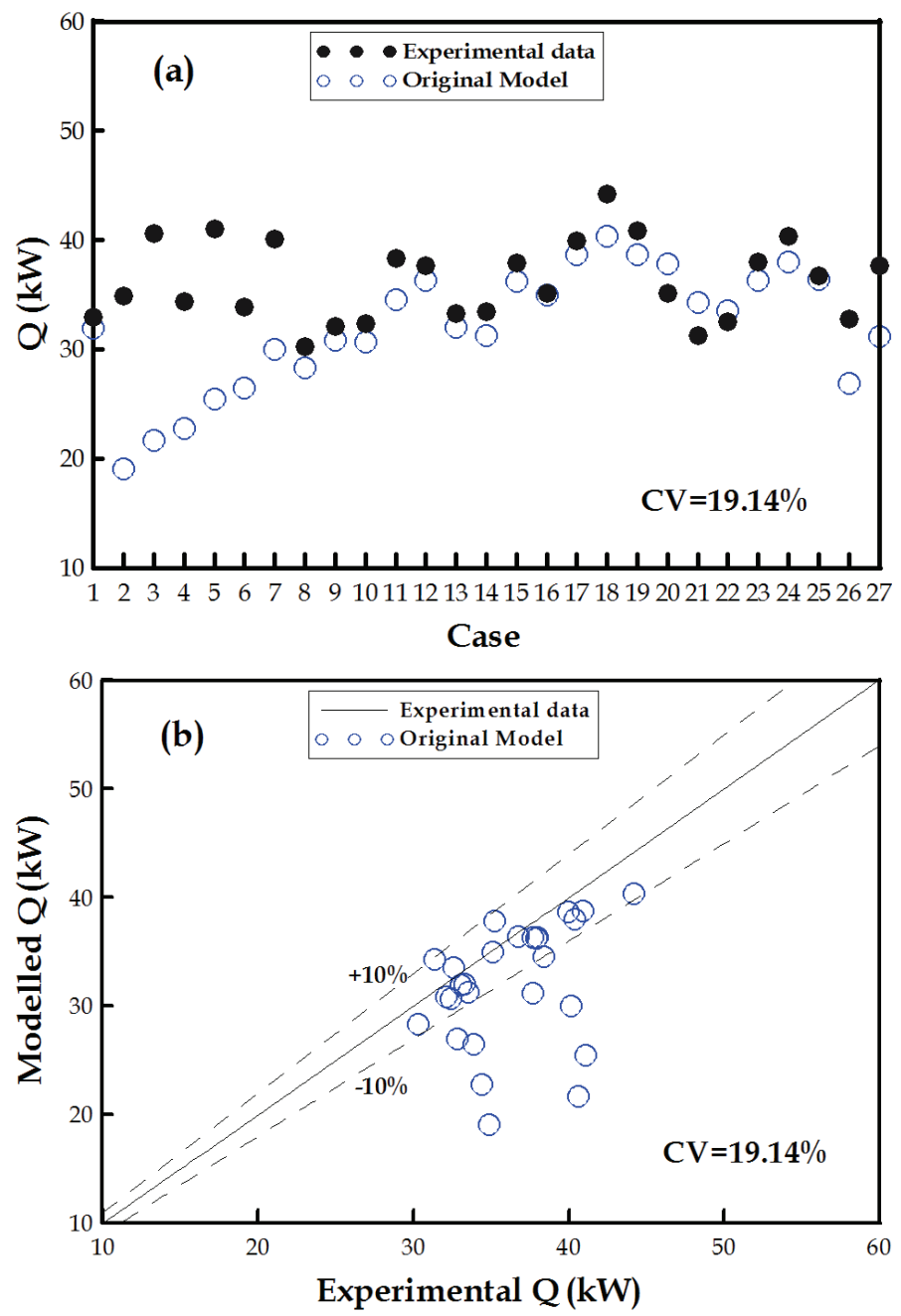

Fig. 7. (a) Comparison between the simulation results and the experimental data, (b) relative error analysis for overall heat transfer rate 
As the water outlet temperature changes due to various physical parameters such as water mass flow rate, the ratio of the model predicted to experimental data for the overall heat transfer coefficient at Section-II, $U_{\text {model,II }} / U_{\text {exp,II }}$, is depicted in Figure 8.

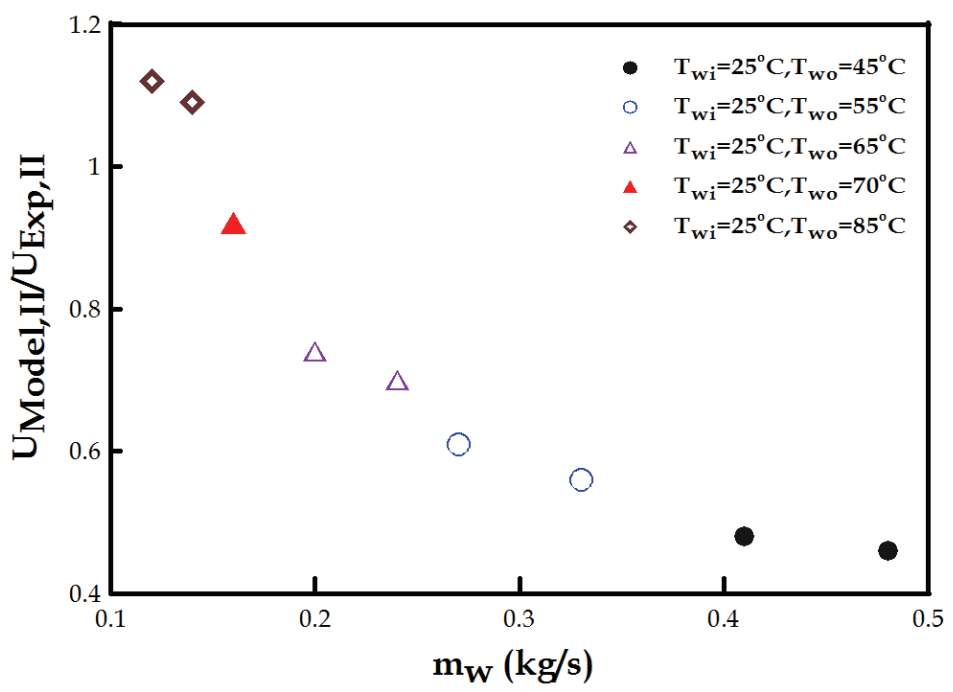

Fig. 8. Variation of the ratio of overall heat transfer coefficient with water mass flow rate under various water outlet temperatures

Figure 8 clearly shows that when the hot water outlet temperature is higher, or when the hot water mass flow rate is lower, the ratio of $U_{\text {Model,II }} / U_{\text {exp,II }}$ becomes larger. This means that as the hot water outlet temperature becomes higher, or when the hot water mass flow rate becomes lower, the simulated value of the overall heat transfer coefficient will change as a result. From this, we can learn that any change in the overall heat transfer coefficient at Section-II has to be related to these two physical parameters. Therefore, modification of the relationship between the overall heat transfer coefficients before and after the change in hot water outlet temperature can be expressed as a function of hot water outlet water temperature and mass flow rate, as Eq. (37) shows:

$$
U^{\prime}{ }_{\text {Model }, I I}=\left(c_{0}+c_{1} T_{w o}+c_{2} \dot{m}_{w}+c_{3} T_{w o} \dot{m}_{w}+c_{4} T_{w o}^{2}+c_{5} \dot{m}_{w}^{2}\right) U_{\text {Model }, I I}
$$

The fitting coefficients in the equation were respectively calculated, using least square regression method, as $c_{0}=3.47931, c_{1}=-0.06503, c_{2}=2.39712, c_{3}=0.018492, c_{4}=0.000340667$, and $c_{5}=-2.68725$.

The modified overall heat transfer coefficient was used to simulate heat transfer rate for condenser. The comparison of model predicting results versus experimental results, and the relative errors are shown in Figure 9a and 9b, respectively.

Using experimental data as a benchmark, the pre-revision calculation error derived from the heat transfer rate prediction model was $19.14 \%$, but post-revision calculation error dropped significantly to $2.03 \%$, indicating that the revision function in Eq. (37) is indeed feasible. Therefore, our study will use the current revision model with modified overall 
heat transfer coefficient for follow-up research with regard to sizing and performance ratings.

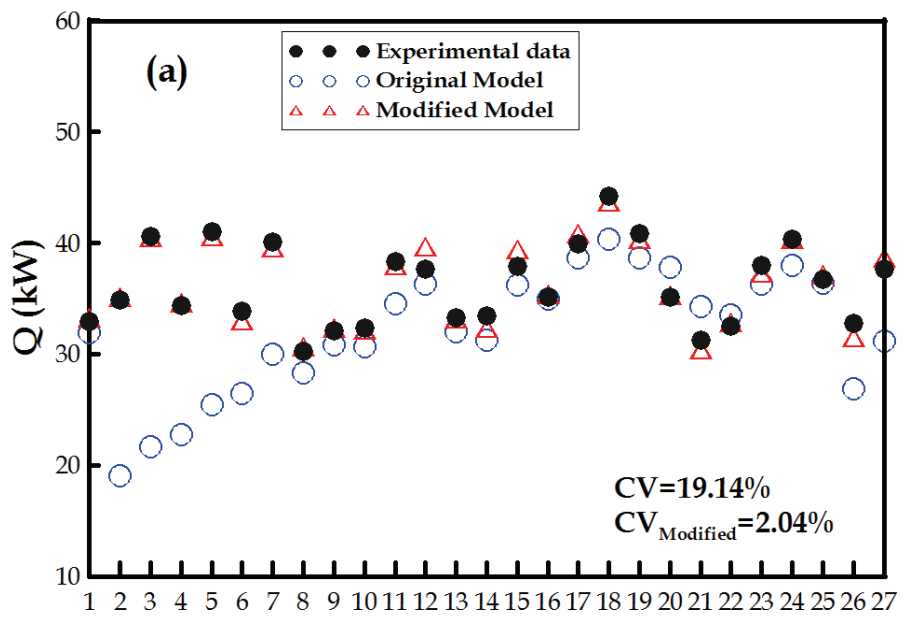

Case

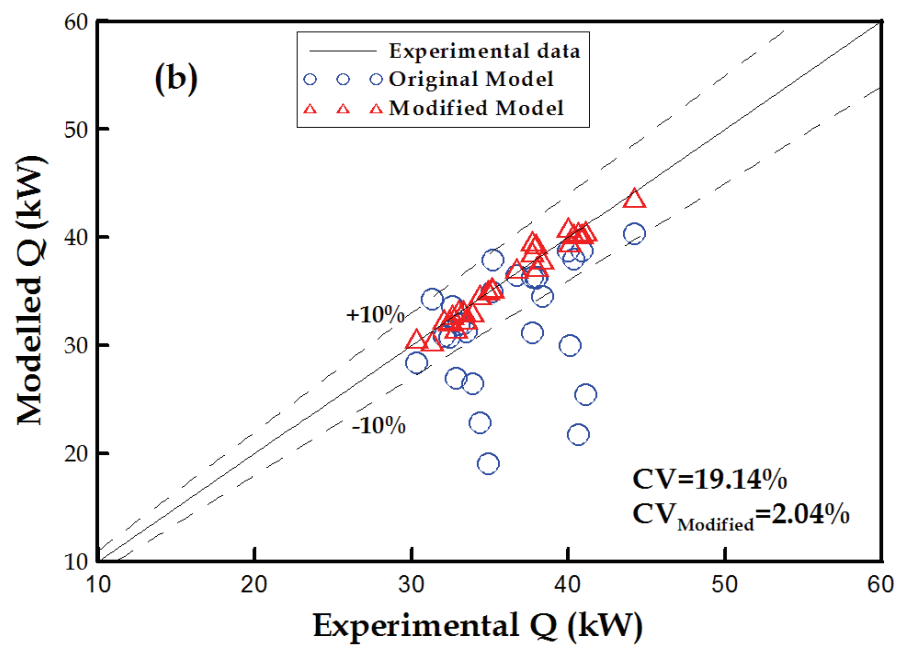

Fig. 9. (a) Comparison between the experimental data and the simulation results by either modified or original models, (b) relative error analysis for overall heat transfer rate

\section{Cases study}

\subsection{Sizing problem (Estimation of unit size)}

Sizing is to estimate the tube length for a heat exchanger by present model when the inlet/outlet conditions on the refrigerant side, the inlet/outlet conditions on the hot water side, and the diameter of the heat exchanger are known. 
The estimation procedures for sizing a shell-and-tube condenser is shown as follows:

- Input design parameters:

- Input design parameters include: refrigerant inlet/outlet temperatures, refrigerant inlet pressure, water inlet/outlet temperatures, water and refrigerant mass flow rates, condensing temperature, number of copper tubes, tube inner/outer diameters, shell inner diameter, baffle spacing, and copper tube spacing.

- Give a tube length and shell-side outlet temperature to be initial guess values for Section-I calculation.

- $\quad$ Calculate the physical properties for Section-I and Section-II.

- Calculate the overall heat transfer rates by present model.

- Check the percent error between model predicting and experimental data for overall heat transfer rates. If the percent error is less than the value of $0.01 \%$, then output the tube length and end the estimation process; if it is larger than the percent error, then set a new value for $L$ and return to the second step.

In accordance with the above estimation procedures, the resulting length is $0.694 \mathrm{~m}$ when input the experimental data set, Case 1, as the design parameters for sizing. The same estimation procedures are utilizing to another 26 cases, and the results are shown in Figure 10 .

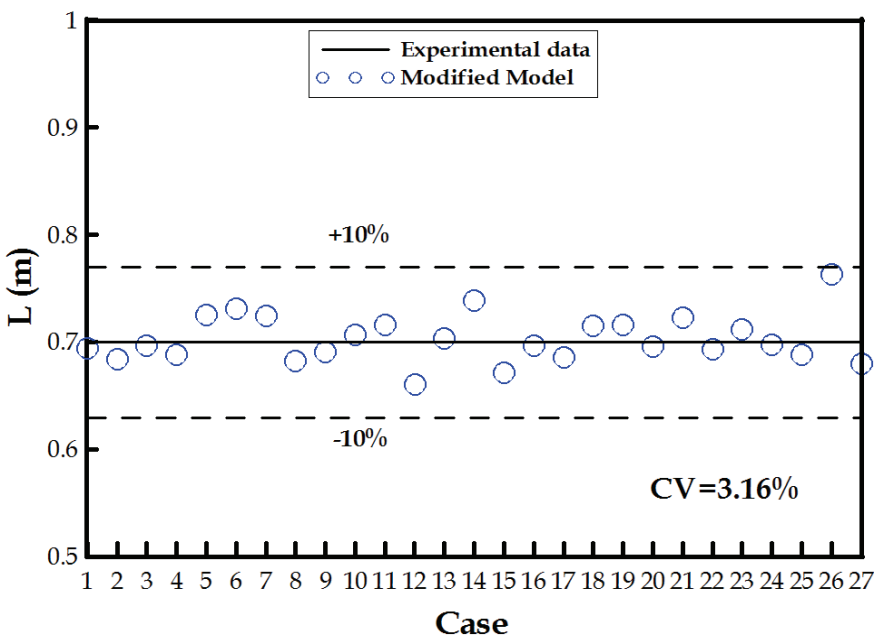

Fig. 10. Estimation results for sizing condensers

Comparisons between the estimating values length for all the cases and the experimental data $(0.7 \mathrm{~m})$ indicats that the relative error were within $\pm 10 \%$ with an average $C V$ value of $3.16 \%$. In summary, the results from the application of present model on heat exchanger sizing calculation are satisfactory.

\subsection{Rating problem (Estimation of thermal performance)}

For performance rating procedure, all the geometrical parameters must be determined as the input into the heat transfer correlations. When the condenser is available, then all the geometrical parameters are also known. In the rating process, the basic calculation is the 
calculations of heat transfer coefficient for both shell- and refrigerant-side stream. If the condenser's refrigerant inlet temperature and pressure, water inlet temperature, hot water and refrigerant mass flow rates, and tube size are specified, then the condenser's water outlet temperature, refrigerant outlet temperature, and heat transfer rate can be estimated.

The estimation process for rating a condenser:

- Input design parameters:

The input design parameters include: refrigerant inlet/outlet temperatures, refrigerant inlet pressure, water inlet temperature, mass flow rate of hot water/refrigerant, and geometric conditions.

- Give a refrigerant outlet temperature as an initial guess for computing the hot water outlet temperature: $T_{w o}=T_{w i}+\frac{\dot{Q}_{w}}{\dot{m}_{w} C_{p w}}$.

- $\quad$ Give an outlet temperature $\left(T_{r}\right)$ as an initial guess for Section-I.

- Calculate the properties for Section-I and Section-II.

- Calculate the overall heat transfer rates by present model.

- Check the percent error between model predicting and experimental data for overall heat transfer rates. If the percent error is less than the value of $0.01 \%$, then output the refrigerant outlet temperature, water outlet temperature, and heat transfer rate; if it is larger than the percent error, then reset a new refrigerant outlet temperature, and return to the second step.

In accordance with the above calculation process, the experimental data of Case 1 can be used as input into the present model for rating calculations. The calculation results give the water outlet temperature is $74.84^{\circ} \mathrm{C}$, refrigerant outlet temperature is $64.35^{\circ} \mathrm{C}$, and heat transfer rate was is $33.01 \mathrm{~kW}$. Experimental data of Case 2 were used as input into the rating calculation process, and another set of result tell: water outlet water temperature is $45.16^{\circ} \mathrm{C}$, refrigerant outlet temperature is $39.04{ }^{\circ} \mathrm{C}$, and heat transfer rate is $35.03 \mathrm{~kW}$. Repeat the same procedures for the remaining 26 sets of experimental data, the calculation results for rating are displayed in Figures 11.

As depicted in Figure 11, comparison of the model predicting and the experimental data for water outlet temperature, refrigerant outlet temperature and heat transfer rates show that the average $\mathrm{CV}$ values are $0.63 \%, 0.36 \%$, and $1.02 \%$ respectively. In summary, the predicting accuracies of present model on shell-and-tube condenser have satisfactory results.

\section{Conclusion}

This study investigated the modelling and simulation of thermal performance for a shelland-tube condenser with longitude baffles, designed for a moderately high-temperature heat pump. Through the validation of experimental data, a heat transfer model for predicting heat transfer rate of condenser was developed, and then used to carry out size estimation and performance rating of the shell-and-tube condenser for cases study. In summary, the following conclusions were obtained:

- A model for calculation, size estimation, and performance rating of the shell-and-tube condenser has been developed, varified, and modified. A good agreement is observed between the computed values and the experimental data.

- In applying the present model, the average deviations (CV) is within $3.16 \%$ for size estimation, and is within $1.02 \%$ for performance rating. 
Modeling and Simulation of the Heat Transfer Behaviour
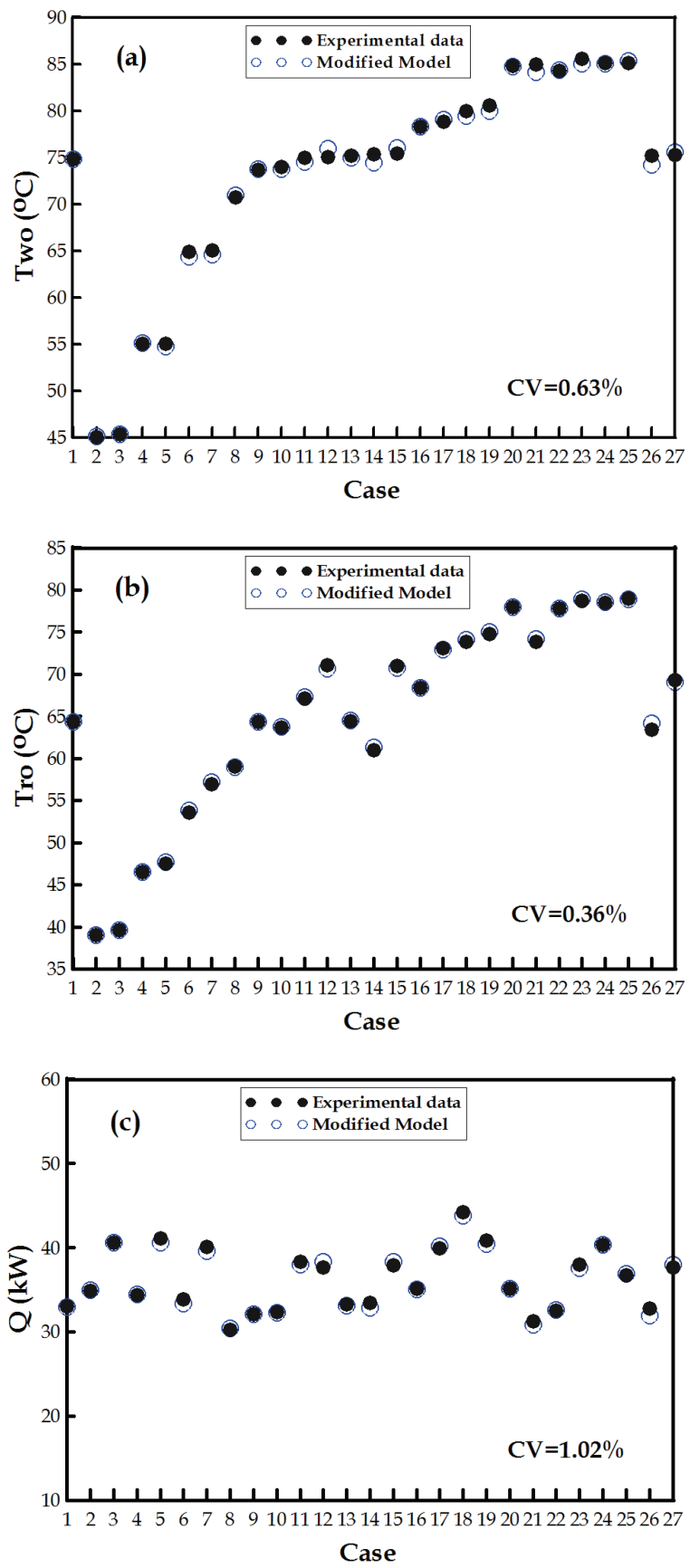

Fig. 11. Simulation results of rating condensers for (a) water outlet temperature, (b) refrigerant outlet temperature, and (c) heat transfer rate 


\section{References}

Allen, B., \& Gosselin, L. (2008). Optimal geometry and flow arrangement for minimizing the cost of shell-and-tube condensers. International Journal of Energy Research, Vol. 32, pp. 958-969.

Caputo, A.C., Pelagagge, P.M., \& Salini, P. (2008). Heat exchanger design based on economic optimisation. Applied Thermal Engineering,Vol. 28, pp. 1151-1159.

Edwards, J.E. (2008). Design and Rating Shell and Tube Heat Exchangers, P \& I Design Ltd, Retrieved from <www.pidesign.co.uk>.

Ghorbani, N., Taherian, H., Gorji, M., \& Mirgolbabaei, H. (2010). An experimental study of thermal performance of shell-and-coil heat exchangers. International communications in Heat and Mass Transfer, Vol. 37, pp. 775-781.

Hewitt, G.F. (1998). Heat Exchanger Design Handbook, ISBN 1-56700-097-5, Begell House, New York.

Holman, J.P. (2000). Heat Transfer, ISBN 957-493-199-4, McGraw-Hill, New York.

Kakac, S., \& Liu, H. (2002). Design correlations for condensers and Evaporators, In:Heat Exchangers, pp. 229-236, CRC press, ISBN 0-8493-0902-6, United Ststes of America.

Kara, Y.A., \& Güraras, Ö. (2004). A computer program for designing of shell-and-tube heat exchangers. Applied Thermal Engineering, Vol. 24, pp. 1797-1805.

Karlsson, T., \& Vamling, L. (2005). Flow fields in shell-and-tube condensers: comparison of a pure refrigerant and a binary mixture. International Journal of Refrigeration, Vol. 28, pp. 706-713.

Karno, A., \& Ajib, S. (2006). Effect of tube pitch on heat transfer in shell-and-tube heat exchangers - new simulation software. Springer-Verlag, Vol. 42, pp. 263-270.

Kern, D.Q. (1950). Process Heat Transfer, ISBN 0070341907, McGraw-Hill, New York.

Li, Y., Jiang, X., Huang, X., Jia, J., \& Tong, J. (2010). Optimization of high-pressure shell-andtube heat exchanger for syngas cooling in an IGCC. International Journal of Heat and Mass Transfer, Vol. 53, pp. 4543-4551.

Moita, R.D., Fernandes, C., Matos, H.A., \& Nunes, C.P. (2004). A Cost-Based Strategy to Design Multiple Shell and Tube Heat Exchangers. Journal of Heat Transfer, Vol. 126, pp. 119-130.

NIST. (2007). REFPROP, In: The United States of America, 2007.

Patel, V.K., \& Rao, R.V. (2010). Design optimization of shell-and-tube heat exchanger using particle swarm optimization technique. Applied Thermal Engineering, Vol. 30, pp. 1417-1425.

Selbas, R., Kızılkan, Ö., \& Reppich, M. (2006). A new design approach for shell-and-tube heat exchangers using genetic algorithms from economic point of view. Chemical Engineering and Processing, Vol. 45, pp. 268-275.

Vera-García, F., García-Cascales, J.R., Gonzálvez-Maciá, J., Cabello, R., Llopis, R., Sanchez, D., \& Torrella, E. (2010). A simplified model for shell-and-tubes heat exchangers: Practical application. Applied Thermal Engineering, Vol. 30, pp. 1231-1241.

Wang, Q.W., Chen, G.D., Xu, J., \& Ji, Y.P. (2010). Second-Law Thermodynamic Comparison and Maximal Velocity Ratio Design of Shell-and-Tube Heat Exchangers with Continuous Helical Baffles. Journal of Heat Transfer, Vol. 132, pp. 1-9. 


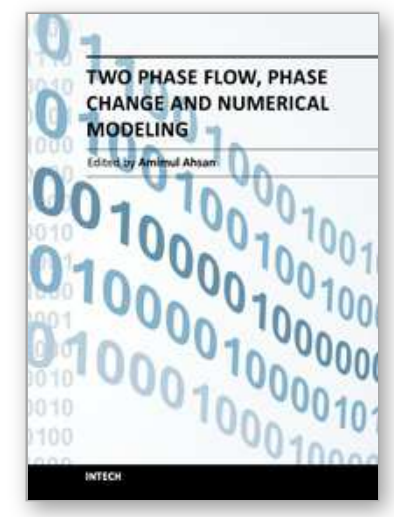

\author{
Two Phase Flow, Phase Change and Numerical Modeling \\ Edited by Dr. Amimul Ahsan
}

ISBN 978-953-307-584-6

Hard cover, 584 pages

Publisher InTech

Published online 26, September, 2011

Published in print edition September, 2011

The heat transfer and analysis on laser beam, evaporator coils, shell-and-tube condenser, two phase flow, nanofluids, complex fluids, and on phase change are significant issues in a design of wide range of industrial processes and devices. This book includes 25 advanced and revised contributions, and it covers mainly (1) numerical modeling of heat transfer, (2) two phase flow, (3) nanofluids, and (4) phase change. The first section introduces numerical modeling of heat transfer on particles in binary gas-solid fluidization bed, solidification phenomena, thermal approaches to laser damage, and temperature and velocity distribution. The second section covers density wave instability phenomena, gas and spray-water quenching, spray cooling, wettability effect, liquid film thickness, and thermosyphon loop. The third section includes nanofluids for heat transfer, nanofluids in minichannels, potential and engineering strategies on nanofluids, and heat transfer at nanoscale. The forth section presents time-dependent melting and deformation processes of phase change material (PCM), thermal energy storage tanks using PCM, phase change in deep $\mathrm{CO} 2$ injector, and thermal storage device of solar hot water system. The advanced idea and information described here will be fruitful for the readers to find a sustainable solution in an industrialized society.

\title{
How to reference
}

In order to correctly reference this scholarly work, feel free to copy and paste the following:

Tzong-Shing Lee and Jhen-Wei Mai (2011). Modeling and Simulation of the Heat Transfer Behaviour of a Shell-and-Tube Condenser for a Moderately High-Temperature Heat Pump, Two Phase Flow, Phase Change and Numerical Modeling, Dr. Amimul Ahsan (Ed.), ISBN: 978-953-307-584-6, InTech, Available from: http://www.intechopen.com/books/two-phase-flow-phase-change-and-numerical-modeling/modeling-andsimulation-of-the-heat-transfer-behaviour-of-a-shell-and-tube-condenser-for-a-moderatel

\section{INTECH}

open science | open minds

\author{
InTech Europe \\ University Campus STeP Ri \\ Slavka Krautzeka 83/A \\ 51000 Rijeka, Croatia \\ Phone: +385 (51) 770447 \\ Fax: +385 (51) 686166 \\ www.intechopen.com
}

\author{
InTech China \\ Unit 405, Office Block, Hotel Equatorial Shanghai \\ No.65, Yan An Road (West), Shanghai, 200040, China \\ 中国上海市延安西路65号上海国际贵都大饭店办公楼 405 单元 \\ Phone: +86-21-62489820 \\ Fax: +86-21-62489821
}


(C) 2011 The Author(s). Licensee IntechOpen. This chapter is distributed under the terms of the Creative Commons Attribution-NonCommercialShareAlike-3.0 License, which permits use, distribution and reproduction for non-commercial purposes, provided the original is properly cited and derivative works building on this content are distributed under the same license. 